\begin{tabular}{lr}
\hline \multicolumn{1}{c}{ D Y N A M I C E C O N O M E T R I C } & M O D E L \\
DOI: http://dx.doi.org/10.12775/DEM.2015.001 & Vol. 15 (2015) 5-26 \\
\hline $\begin{array}{l}\text { Submitted September 11, 2015 } \\
\text { Accepted December 15, 2015 }\end{array}$ & ISSN (online) 2450-7067 \\
ISSN (print) 1234-3862
\end{tabular}

\title{
Spatio-temporal Analysis of Convergence of Development Level of Selected Stock Exchanges in the Period of 2004-2012
}

\begin{abstract}
A b s t r a c t. The paper concerns the convergence of selected stock exchanges from the point of view of their development. It presents the methodological approach which points up taking into account spatial and economic connections among stock markets in convergence analyses. In this analysis the need for division of the stock exchanges according to a spatial regimes is pointed up as well. The research includes 42 largest trading floors analyzed in the period of 2004-2012. The empirical data refer to six diagnostic variables acknowledged as the important determinants of the development of stock markets.
\end{abstract}

K e y w o r d s: stock exchanges, convergence, spatial regimes, physical and economic distance, connectivity matrix, spatial panel models.

J E L Classification: C10, C12, C58, G15.

\section{Introduction}

The paper concerns the convergence of selected stock exchanges, with European stock exchanges on the one hand and the Asian and American on the other, from the point of view of their development. The study is a continuation of our previous investigation, the results of which were published in Dynamic Econometric Models, 2014 (14) (Szulc et al., 2014, pp. 125$-144)$. The main findings of the quoted work were as follows: (1) Including the linkages that result from physical and/or economic distance between

\footnotetext{
* Correspondence to: Elżbieta Szulc, Nicolaus Copernicus University, Department of Econometrics and Statistics, ul. Gagarina 13A, 87-100 Toruń, Poland, e-mail: eszulc@umk.pl

(C) 2015 Nicolaus Copernicus University Press. All rights reserved. http://www.dem.umk.pl/dem
} 
stock exchanges in their convergence models is justified and crucial for the analysis of this phenomenon. (2) As a result, it is possible to define the influence of the distance between exchanges on their economic development, the estimates of convergence parameter are more precise, and some statistical properties of the models are better. (3) Due to the heteroskedasticity, the empirical panel models for the exchanges investigated as a whole were not entirely satisfactory. It means that there are differentials in relationship between objects considered and their speed of convergence. (4) In some empirical models which we obtained there appeared the problem of autocorrelation of residuals.

Motivated by the desire to improve the properties of the empirical models, firstly we decided to establish some spatial regimes and then repeat the research with the division of stock exchanges. The applied categorization involved placing European stock exchanges on one side, and the American and Asian stock markets on the other. The validity of this choice was confirmed by the results of the Chow test on spatial variability of the model parameters (Arbia 2006, p. 133) presented in Section 4 of this paper.

The discussion on the convergence of stock exchanges is associated with one of the directions of the analysis of the relationship between capital markets, which searches out the ever-increasing convergence of these markets from the point of view of their specific characteristics. This process, which can be referred to as convergence of stock exchanges is associated with an integration of the financial markets, and their growing interdependence, which in turn is associated with the liberalization of capital flows and technological progress. These processes are favorable for further development of stock markets, and thus the distinctions between them are becoming increasingly blurred over time.

The problem of convergence of equity markets has already been considered in the literature on the subject, e.g. Aspergis, Christou, Miller (2014), Koralun-Bereźnicka (2008), Fraser, Helliar, Power (1994), Caporale, Erdogan, Kuzin (2009). In particular, the papers presenting the analysis of convergence of the stock exchanges with the prospect of space are the most interesting, e.g. Asgharian, Hess, Liu (2013), Suchecka, Łaszkiewicz (2011), Wójcik (2009). The literature indicates the validity of the analysis of the relationship between capital markets having regard on their location in the geographic space, and also takes into account the so-called economic distance between these markets. This paper refers to such a methodological approach.

The aim of the paper is to investigate whether, in the light of the current empirical analyses, one may observe the process of convergence of the main 
European as well as American and Asian stock markets. In addition, the importance of distance between the markets for the process is evaluated. Particularly, the role of economic distance is considered. The research is aimed to verify the hypothesis that the relative location of a stock market in the geographic as well as a particular economic space affects its growth rate.

The achievement of the objective and verification of the research hypothesis was enabled through: defining a taxonomic measure of development of exchanges, then building of empirical dynamic models of stock exchanges' convergence for pooled time series and cross-sectional data and for panel data in the traditional version, which ignore spatial and economic linkages between stock exchanges and dynamic spatial models (including spatial panel models), i.e. models with regard to the described relationship, and finally the comparison of statistical properties and the interpretation values of model' parameters in various versions.

\section{Subject and Range of the Investigation}

The subject of the investigation contains the selected European, Asian and American stock exchanges, characterized in terms of their level of development. The study included 42 largest trading floors in the period of 2004-2012. The specification of the exchanges with the assignment to the relevant country is presented in Table 1.

The level of stock exchange development was defined by a synthetic measure based on six diagnostic variables, i.e. X1 - the capitalization of domestic shares, X2 - the capitalization of newly listed domestic shares, X3 - the total value of share trading, X4 - GDP per capita, X5 - the top 10 most heavily capitalized domestic companies, X6 - the ratio of market capitalization to GDP. It was recognized that, in the light of theory and empirical analyses, the specified variables are important determinants of the development of stock exchanges (see e.g. Demirgur-Kunt and Levine, 1996; Levine and Zelvos, 1996; Łuniewska and Tarczyński, 2006; Szulc et al., 2014; Wiśniewski, 2003). Taking into account the connections of the capital market with the economy of the country of its location was also an important issue for the specification of the diagnostic variables. The range of information provided by the World Federation of Exchanges (www.worldexchanges.org), whence we get the data, played a significant role as well. 
Table 1. Specification of the stock exchanges considered

\begin{tabular}{|c|c|c|c|}
\hline \multicolumn{4}{|c|}{ North.South America and Asia } \\
\hline Brazil & BM\&BOVESPA (BOV) & Chile & Santiago SE (SSE) \\
\hline Canada & TMX Group (TMX) & Colombia & Colombia SE (CSE) \\
\hline Mexico & $\begin{array}{l}\text { Mexican Exchange } \\
\text { (BMV) }\end{array}$ & Bermuda & Bermuda SE (BSX) \\
\hline Argentina & $\begin{array}{l}\text { Buenos Aires SE } \\
\text { (BCBA) }\end{array}$ & Peru & Lima SE (BVL) \\
\hline United States & $\begin{array}{c}\text { Nasdaq OMX } \\
\text { (NASDAQ) } \\
\text { Nyse Euronext (US) } \\
\text { (NYSE) }\end{array}$ & Singapore & Singapore SE (SE) \\
\hline Thailand & Thailand SE (THSE) & Philippines & Phillippine SE (PSE) \\
\hline China & $\begin{array}{c}\text { Honk Kong SE (SEHK) } \\
\text { Shanghai SE (SHSE) } \\
\text { Shenzen SE (SZSE) } \\
\text { Taiwan SE Corp. } \\
\text { (TSEC) }\end{array}$ & Japan & $\begin{array}{c}\text { Osaca SE (OSE) } \\
\text { Tokyo SE Group } \\
\text { (TSE) }\end{array}$ \\
\hline India & $\begin{array}{l}\text { National SE India } \\
\text { (NSE) }\end{array}$ & Indonesia & Indonesia SE (ISE) \\
\hline South Korea & Korea Exchange (KRX) & Malaysia & Bursa Malaysia (BM) \\
\hline Sri Lanka & Colombo SE (CLSE) & & \\
\hline \multicolumn{4}{|c|}{ Europe } \\
\hline Austrian & Wiener Borse (AG) & Cyprus & Cyprus SE (CPSE) \\
\hline Egypt & $\begin{array}{c}\text { Cairo\&Alexandria SE } \\
(E G X)^{*}\end{array}$ & Greece & $\begin{array}{c}\text { Athens Exchange } \\
\text { (ATHEX) }\end{array}$ \\
\hline Spain & $\begin{array}{l}\text { BME Spanish Ex- } \\
\text { change (BME) }\end{array}$ & Netherlands & $\begin{array}{l}\text { Nyse Euronext } \\
\text { (Europe) (NEE) }\end{array}$ \\
\hline Turkey & Istanbul SE (ISSE) & Ireland & Irish SE (IRSE) \\
\hline Israel & Tel Aviv SE (TASE)* & Luxemburg & $\begin{array}{l}\text { Luxemburg SE } \\
\text { (LXSE) }\end{array}$ \\
\hline Malta & Malta SE (MSE) & Hungary & Budapest SE (BDSE) \\
\hline Germany & Deutsche Borse (DB) & Norway & Oslo Bors (OBE) \\
\hline Poland & Warsaw SE (WSE) & Great Britain & London SE (LSE) \\
\hline Switzerland & $\begin{array}{l}\text { SIX Swiss Exchange } \\
(\mathrm{SIX})\end{array}$ & Sweden & $\begin{array}{l}\text { Nasdaq OMX Nordic } \\
\text { Exchange (NOMX) }\end{array}$ \\
\hline
\end{tabular}

\section{Methodology}

The research was conducted in relation to the aggregate characteristic of the stock exchanges in the form of a taxonomic measure of development. This indicator is understood as a synthetic normalized formula expressed by (see Hellwig, 1968):

Dynamic Econometric Models 15 (2015) 5-26 


$$
q_{i}^{\prime}=1-\frac{q_{i}}{\bar{q}+2 S_{q}},
$$

where:

$q_{i}$ - the synthetic variable determining the level of development of the $i$-th exchange in relations to a development standard,

$\bar{q}-$ the average value of the synthetic variable,

$S_{q}$ - the standard deviation of the variable.

In this approach the values of the synthetic variable $q_{i}$ are calculated according to the formula:

$$
q_{i}=\sqrt{\sum_{j=1}^{m}\left(z_{i j}-z_{0 j}\right)^{2}},
$$

where:

$z_{i j}-$ the value of $j$-th diagnostic variable for $i$-th exchange standardized to $0-1$,

$z_{0 j}-$ the value of $j$-th diagnostic variable for the standard of development standardized to $0-1$.

Thus, $q_{i}$ means a distance between $i$-th exchange and the development standard.

Through the use of the taxonomic measure of stock exchanges' development it is possible to present the rankings of exchanges and their changes in time, the evaluation of the correlation between stock exchanges in terms of development, the identification of linkages between markets in an economic space, and finally, the analysis of the stock exchanges' convergence, which is meant as equalizing their development levels. In this paper we focus on the examination of the concept of exchanges' convergence, in the light of which the stock market with an initial lower level of development showed a faster growth rate in the considered measure of development.

The analysis of the stock exchanges' convergence was based on econometric models of $\beta$-convergence, in particular, the spatial models for pooled time series and cross-sectional data (TSCS) as well as spatial panel models. The same classes of models were used previously (Szulc et al., 2014).The premises for the application of spatial models are as follows:

- The result of including the spatial linkages between stock exchanges in the models of their convergence is better evaluation of the convergence phenomenon on the grounds of $\beta$ parameter estimated. The estimate of 
the parameter reflects more accurately the impact of the base level of development of a given stock exchange on the growth rate of the stock exchange characteristics in question because such estimate is not influenced by omitting spatial relationship.

- The use of spatial models provides the opportunity to measure and interpret the impact of connections of a given stock exchange with others on its development.

The spatial models for pooled time series and cross-sectional data (TSCS) are presented by formulas 3 and 4, whereas the formulas 5 and 6 refer to the spatial panel models.

The model TSCS with spatial component takes the form of the spatial autoregressive model (SAR_pooled), i.e.:

$$
\ln \left[\frac{q_{i t}^{\prime}}{q_{i t-1}^{\prime}}\right]=\alpha+\beta \ln \left[q_{i t-1}^{\prime}\right]+\rho \sum_{j \neq i} w_{i j} \ln \left[\frac{q_{j t}^{\prime}}{q_{j t-1}^{\prime}}\right]+\varepsilon_{i t},
$$

or of the model with spatial autoregressive residuals (SE_pooled), i.e.:

$$
\ln \left[\frac{q_{i t}^{\prime}}{q_{i t-1}^{\prime}}\right]=\alpha+\beta \ln \left[q_{i t-1}^{\prime}\right]+\eta_{i t}, \eta_{i t}=\lambda \sum_{j \neq i} w_{i j} \eta_{j t}+\varepsilon_{i t} .
$$

The spatial panel models used in the investigation were as follows:

$$
\ln \left[\frac{q_{i t}^{\prime}}{q_{i t-1}^{\prime}}\right]=\alpha_{i}+\beta \ln \left[q_{i t-1}^{\prime}\right]+\rho \sum_{j \neq i} w_{i j} \ln \left[\frac{q_{j t}^{\prime}}{q_{j t-1}^{\prime}}\right]+\varepsilon_{i t},
$$

i.e. the spatial autoregressive panel model with individual fixed effects (the spatial autoregressive fixed-effect model) (SAR_FE_IND) and

$$
\ln \left[\frac{q_{i t}^{\prime}}{q_{i t-1}^{\prime}}\right]=\alpha_{i}+\beta \ln \left[q_{i t-1}^{\prime}\right]+\eta_{i t}, \quad \eta_{i t}=\lambda \sum_{j \neq i} w_{i j} \eta_{j t}+\varepsilon_{i t},
$$

i.e. the spatial error panel model with individual fixed effects (SE_FE_IND).

Elements $w_{i j}$ in the formulas (3)-(6) come from connectivity matrix $\mathbf{W}$ which refers to the linkages between exchanges considered. Various types of weights $w_{i j}$ may be pointed out according to the established criteria (see e.g. Haining, 2005, pp. 83-84).

In this paper the linkages between stock exchanges will be defined with the use of two approaches. The first uses a matrix of connections with weights established on the basis of the physical distance between the centers of the countries where the stock exchanges are located. The second consists 
in the consideration of the economic distance in the matrix of connections. The essence of the second approach is to establish similarity of the exchanges on the basis of the value of the taxonomic measure of exchanges' development.

The quantification of the spatial linkages between stock exchanges on the basis of the geographical distance was carried out according to the following scheme:

1. Determining the spatial relationships using the linkages matrix $\mathbf{S}$, with elements:

$$
s_{i k}=\left\{\begin{array}{l}
\frac{1}{d_{i k}}, \text { if } i \neq k \\
0, \text { if } i=k,
\end{array}\right.
$$

where: $d_{i k}$ - the physical distance between capitals of the countries where the $i$-th and the $k$-th stock exchanges are located.

2. Row standardization of the connectivity matrix to one, i.e.:

$$
w_{i k}=\frac{s_{i k}}{\sum_{k=1}^{N} s_{i k}} .
$$

3. Construction of the block matrix of connections, i.e.:

$$
\mathbf{W}=\left[\begin{array}{cccc}
\mathbf{W}_{1} & \mathbf{0} & \cdots & \mathbf{0} \\
\mathbf{0} & \mathbf{W}_{2} & \cdots & \mathbf{0} \\
\vdots & \vdots & \ddots & \vdots \\
\mathbf{0} & \mathbf{0} & \cdots & \mathbf{W}_{9}
\end{array}\right]
$$

where: $\mathbf{W}_{1}=\mathbf{W}_{2}=\ldots=\mathbf{W}_{9}$ - matrixes of the spatial connections based on the physical distance, the same for all the considered years.

In the second approach, i.e. with the use of an economic distance between stock exchanges, the following scheme was used:

1. Determining the linkages between stock exchanges with the use of an economic distance, expressed by the formula:

$$
d_{i k}=\sqrt{\sum_{j=1}^{m}\left(z_{i j}-z_{k j}\right)^{2}},
$$

where: $d_{i k}-$ the economic distance between $i$-th and $k$-th stock exchange, 
$z_{i j}, z_{k j}$ - the values of standardized diagnostic variables for each $i$-th and $k$-th stock exchange,

$j=1,2, \ldots, 6-$ the number of the diagnostic variable.

2. Construction of the matrix of linkages between stock exchanges, with elements:

$$
w_{i k}=\left\{\begin{array}{l}
\frac{1}{d_{i k}}, \text { if } i \neq k \\
0, \text { if } i=k .
\end{array}\right.
$$

3. Row standardization of the connectivity matrix to one, i.e.:

$$
w_{i k}^{*}=\frac{w_{i k}}{\sum_{k=1}^{N} w_{i k}} .
$$

4. Construction of the block matrix of cross-sectional and time connections which may be described in the following form:

$$
\mathbf{W}^{*}=\left[\begin{array}{cccc}
\mathbf{W}^{*}{ }_{1} & \mathbf{0} & \cdots & \mathbf{0} \\
\mathbf{0} & \mathbf{W}^{*}{ }_{2} & \cdots & \mathbf{0} \\
\vdots & \mathbf{0} & \ddots & \vdots \\
\mathbf{0} & \mathbf{0} & \cdots & \mathbf{W}^{*}
\end{array}\right],
$$

where: $\mathbf{W}^{*}{ }_{1} \neq \mathbf{W}^{*}{ }_{2} \neq \ldots \neq \mathbf{W}^{*}{ }_{9}$ - matrixes of connections, taking into account the economic distance between exchanges, different for successive years.

In order to evaluate the quality of the empirical models in the investigation the following tools were used: the Moran test for verifying spatial independence of the residuals, the Lagrange Multiplier tests (LMlag, LMerr) and their robust versions (RLMlag, RLMerr) as spatial dependence diagnostics, the Likelihood Ratio test (LR) for testing the significance of the spatial dependence, the Breusch-Pagan heteroskedasticity test, the Chow test for verifying the spatial changeability of $\beta$ parameters and the need for including fixed effects in the spatial panel models (on the tools see e.g. Arbia, 2006; Millo and Piras, 2012; Mutl and Pfaffermayr, 2011; Baltagi et al., 2003; Suchecki (ed.), 2012).

All calculations were performed with $\mathrm{R}$ (version 3.0.1) and the graphical illustrations - with the use of MapViever and Corel. 


\section{Preliminary Data Analysis}

Figure 1 shows locations of the investigated exchanges on the world map and bar charts of taxonomic measure of development (TMD) in the years 2004-2012. This presentation allows us to observe changes in the level of development of the individual stock exchanges and a comparison of the dynamics of changes by their spatial location as well. It is worth noting that most of the developing economies' stock exchanges, both on the European continent, as well as American and Asian, are characterized by a relatively stable level of the taxonomic measure of development throughout the whole adopted time horizon, even during a sharp slowdown in the economic conditions caused by the global financial crisis. This finding is particularly evident in relation to such exchanges as e.g. BCBA, BVL, SSE, BDSE, EEZ, CLSE, ISE, PSE.

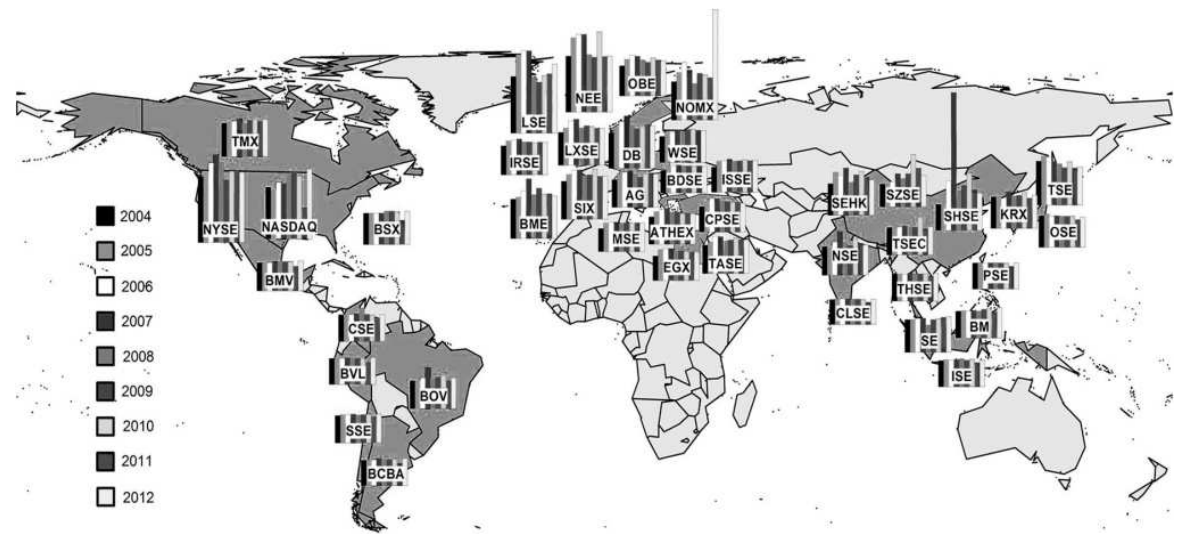

Figure 1. Bar charts of TMD for the investigated stock exchanges in the years 2004-2012

Figures 2 and 3 show the value of the taxonomic measure of development (surface of the wheel) for each stock exchange included in the study for the year 2004 and 2012, respectively. This graphical presentation is useful for a preliminary assessment of changes in the global capital market over the considered period. In 2004, two dominant financial centers are clearly visible. In the west, it is NYSE and NASDAQ, while in central Europe, the London Stock Exchange and NYSE Euronext Europe stand out in particular. In turn, in 2012 a slight strengthening of the position of the two largest US stock exchanges: NYSE and NASDAQ may be observed. However, the most spectacular changes can be seen in the case of the NOMX Central European stock exchange. NOMX has strengthened at the expense of two neighboring 
stock exchanges LSE and NEE, gaining a leading position in 2012 and clearly outperforming their level of development. With regard to the second group of the analyzed exchanges, there were no significant changes in the values of the synthetic measure of development. Therefore NYSE and NASDAQ are again placed in the dominant position of the ranking.

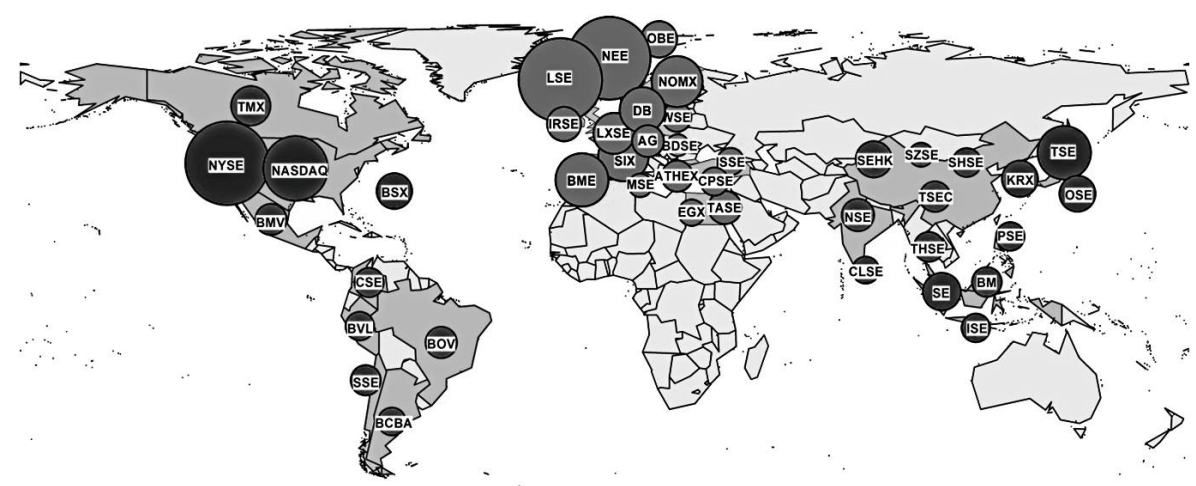

Figure 2. The taxonomic measure of stock exchanges' development in 2004

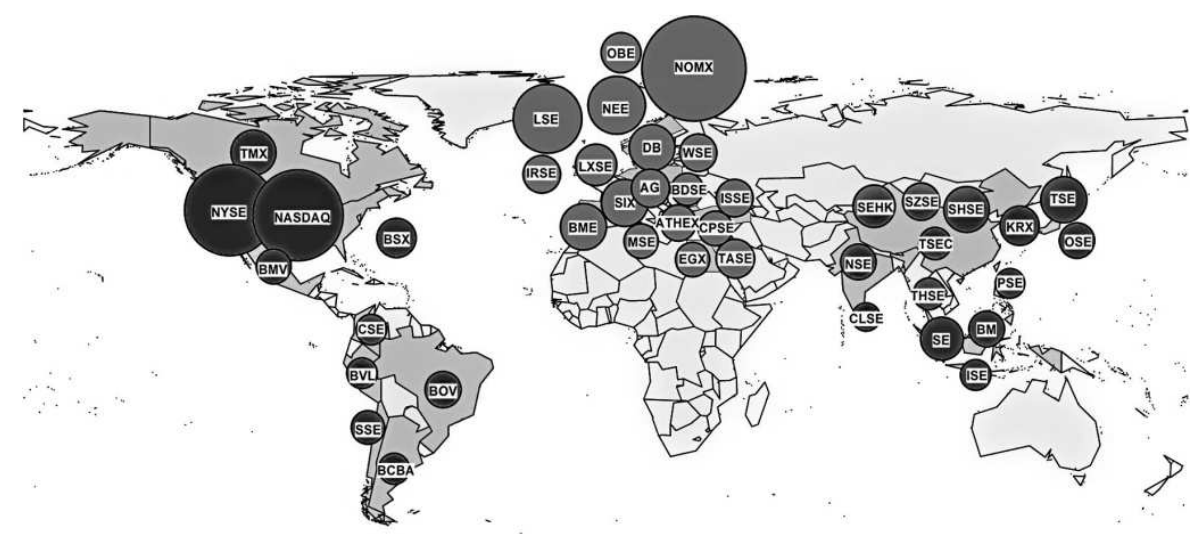

Figure 3. The taxonomic measure of stock exchanges' development in 2012

\section{Results of the Econometric Analysis}

In order to justify the division of the considered stock exchanges into two groups the Chow test of spatial changeability of $\beta$ parameters was applied. The results are presented in Table 2 . The hypothesis that parameters in $\beta$-convergence models estimated in the investigation are constant should be rejected. This leads to the identification of spatial regimes and means that the 
convergence of the European and Asian/American stock markets should be investigated separately.

Table 2. Results of the tests for spatial invariance of the $\beta$-convergence parameters

\begin{tabular}{cccccc}
\hline \multirow{2}{*}{ Models } & \multirow{2}{*}{ Linear regression } & \multicolumn{2}{c}{$\begin{array}{c}\text { Spatial autoregressive } \\
\text { model }\end{array}$} & \multicolumn{2}{c}{$\begin{array}{c}\text { Spatial error } \\
\text { model }\end{array}$} \\
\cline { 3 - 6 } & & Variant I & Variant II & Variant I & Variant II \\
\hline Values of Chow test & 210.709 & 113.517 & 117.036 & 113.557 & 121.783 \\
p-value & 0.0000 & 0.0000 & 0.0000 & 0.0000 & 0.0000 \\
\hline
\end{tabular}

The successive tables presented below contain information on the usefulness of various methodological concepts expressed by the spatial models presented in Section 2, in comparison with the linear regression model, i.e. the traditional model not including the spatial effects. Tables 3-6 refer to the empirical models obtained for the European stock exchanges, and tables $7-$ -10 for the Asian and American stock exchanges.

In Tables 3 and 4 there are presented the results of the estimation and verification of the three models for pooled time series and cross-sectional data: the linear regression model (TSCS), the spatial autoregressive model (SAR_pooled) and the spatial error model (SE_pooled). Table 3 contains the results obtained in the case when, for the purpose of quantification of the connections among the investigated exchanges, the matrix $\mathbf{W}$ of the physical distance between them was used (variant I). Table 4 presents the analogical results, but in the spatial models there was used the connectivity matrix $\mathbf{W}^{*}$ of the economic distance between the exchanges (variant II).

The classical model estimated with the use of the pooled time series and cross-sectional data does not satisfy the fundamental criteria of statistical verification. The main drawback of this model is autocorrelation of residuals, which is confirmed by the result of the Moran test (see Tables 3 and 4).

In order to propose an alternative opposed to the classical model the Lagrange Multiplier tests (LM) were used (see Tables 3 and 4). The LM tests for the linear model for the pooled time series and cross-sectional data used consider the spatial lag model (spatial autoregressive) and the spatial error model as alternatives (LMlag and LMerr, respectively). Tables 3 and 4 report the results of using the robust tests (RLMlag, in which $\mathrm{H}_{0}: \rho=0$ under the assumption that $\lambda \neq 0$ and RLMerr, where $\mathrm{H}_{0}: \lambda=0$ under the assumption that $\rho \neq 0$ ) as well. 
Table 3. Results of the estimation and verification of $\beta$-convergence models for pooled time series and cross-sectional data, obtained for European stock exchanges - variant I

\begin{tabular}{|c|c|c|c|}
\hline & Linear regression & $\begin{array}{c}\text { Spatial autoregressive } \\
\text { model }\end{array}$ & $\begin{array}{c}\text { Spatial error } \\
\text { model }\end{array}$ \\
\hline \multicolumn{4}{|l|}{ Parameters } \\
\hline$\alpha$ & $\begin{array}{l}-0.2087 \\
(0.0055)\end{array}$ & $\begin{array}{l}-0.1316 \\
(0.0275)\end{array}$ & $\begin{array}{l}-0.0533 \\
(0.4338)\end{array}$ \\
\hline$\beta$ & $\begin{array}{l}-0.1356 \\
(0.0007)\end{array}$ & $\begin{array}{l}-0.0789 \\
(0.0128)\end{array}$ & $\begin{array}{l}-0.0527 \\
(0.0704)\end{array}$ \\
\hline$\rho$ & - & $\begin{array}{c}0.6779 \\
(0.0000)\end{array}$ & - \\
\hline$\lambda$ & - & - & $\begin{array}{c}0.6964 \\
(0.0000) \\
\end{array}$ \\
\hline \multicolumn{4}{|l|}{ Goodness of fit } \\
\hline Adjusted R2 & 0.0711 & - & - \\
\hline $\mathrm{AIC}$ & -60.5170 & -109.7800 & -107.0800 \\
\hline \multicolumn{4}{|l|}{ Heteroskedasticity } \\
\hline Breuch-Pagan test & $\begin{array}{c}3.2874 \\
(0.0698) \\
\end{array}$ & $\begin{array}{c}2.2977 \\
(0.1296) \\
\end{array}$ & $\begin{array}{l}2.7537 \\
(0.0970) \\
\end{array}$ \\
\hline $\begin{array}{c}\text { Autocorrelation of } \\
\text { residuals } \\
\text { Moran test }\end{array}$ & $\begin{array}{r}11.9203 \\
(0.0000) \\
\end{array}$ & $\begin{array}{l}-1.1350 \\
(0.1282) \\
\end{array}$ & $\begin{array}{l}-0.6776 \\
(0.2490) \\
\end{array}$ \\
\hline \multicolumn{2}{|l|}{ dependence } & & \\
\hline LR & - & $\begin{array}{l}51.2580 \\
(0.0000)\end{array}$ & $\begin{array}{l}48.5600 \\
(0.0000)\end{array}$ \\
\hline LMlag & $\begin{array}{l}145.0560 \\
(0.0000)\end{array}$ & - & - \\
\hline LMerr & $\begin{array}{l}116.1595 \\
(0.0000)\end{array}$ & - & - \\
\hline RLMlag & - & $\begin{array}{l}35.9081 \\
(0.0000)\end{array}$ & - \\
\hline RLMerr & - & - & $\begin{array}{l}7.0116 \\
(0.0081)\end{array}$ \\
\hline $\begin{array}{c}\text { Speed of convergence } \\
\text { Half-life }\end{array}$ & $\begin{array}{l}0.0182 \\
38,05\end{array}$ & $\begin{array}{l}0.0103 \\
67.47 \\
\end{array}$ & $\begin{array}{l}0.0068 \\
102.42 \\
\end{array}$ \\
\hline
\end{tabular}

Note: Numbers in brackets refer to the p-values.

Since the LMlag tests are more significant than the LMerr, and the RLMlag tests are more significant than the RLMerr, the spatial lag models should be preferred. Subsequently, the significance of the spatial effects in the SAR and SE models using the Likelihood Ratio test (LR) was confirmed (see Tables 3 and 4). The results show that the statistical properties of the obtained empirical models are the same (the spatial autocorrelation of residuals of linear regression model, significant LM statistics and significant spatial 
effects confirmed by the LR test), irrespective of which connectivity matrix (of physical or of economic distance) was used in the spatial models.

Table 4. Results of the estimation and verification of $\beta$-convergence models for pooled time series and cross-sectional data, obtained for European stock exchanges - variant II

\begin{tabular}{|c|c|c|c|}
\hline & Linear regression & $\begin{array}{c}\text { Spatial autoregressive } \\
\text { model }\end{array}$ & $\begin{array}{c}\text { Spatial error } \\
\text { model }\end{array}$ \\
\hline \multicolumn{4}{|l|}{ Parameters } \\
\hline$\alpha$ & $\begin{array}{l}-0.2087 \\
(0.0055)\end{array}$ & $\begin{array}{l}-0.1219 \\
(0.0336)\end{array}$ & $\begin{array}{l}-0.0638 \\
(0.4084)\end{array}$ \\
\hline$\beta$ & $\begin{array}{l}-0.1356 \\
(0.0007)\end{array}$ & $\begin{array}{l}-0.0747 \\
(0.0144)\end{array}$ & $\begin{array}{l}-0.0800 \\
(0.02534)\end{array}$ \\
\hline$\rho$ & - & $\begin{array}{c}0.7442 \\
(0.0000)\end{array}$ & - \\
\hline$\lambda$ & - & - & $\begin{array}{c}0.7920 \\
(0.0000)\end{array}$ \\
\hline \multicolumn{4}{|l|}{ Goodness of fit } \\
\hline Adjusted R2 & 0.0711 & - & - \\
\hline AIC & -60.5170 & -118.4300 & -117.5600 \\
\hline \multicolumn{4}{|l|}{ Heteroskedasticity } \\
\hline Breuch-Pagan test & $\begin{array}{c}3.2874 \\
(0.0698) \\
\end{array}$ & $\begin{array}{c}2.2312 \\
(0.1353) \\
\end{array}$ & $\begin{array}{c}2.1093 \\
(0.1464) \\
\end{array}$ \\
\hline $\begin{array}{l}\text { Autocorrelation of } \\
\text { residuals } \\
\text { Moran test }\end{array}$ & $\begin{array}{l}12.9587 \\
(0.0000)\end{array}$ & $\begin{array}{c}1.4475 \\
(0.0739)\end{array}$ & $\begin{array}{c}1.7664 \\
(0.0387)\end{array}$ \\
\hline \multicolumn{4}{|l|}{$\begin{array}{c}\text { Spatial } \\
\text { dependence }\end{array}$} \\
\hline LR & - & $\begin{array}{l}59.9100 \\
(0.0000)\end{array}$ & $\begin{array}{l}59.0380 \\
(0.0000)\end{array}$ \\
\hline LMlag & $\begin{array}{l}156.2542 \\
(0.0000)\end{array}$ & - & - \\
\hline LMerr & $\begin{array}{l}137.3223 \\
(0.0000)\end{array}$ & - & - \\
\hline RLMlag & - & $\begin{array}{l}27.8846 \\
(0.0000)\end{array}$ & - \\
\hline RLMerr & - & - & $\begin{array}{l}8.9527 \\
(0.0028) \\
\end{array}$ \\
\hline $\begin{array}{c}\text { Speed of convergence } \\
\text { Half-life }\end{array}$ & $\begin{array}{l}0.0182 \\
38.05\end{array}$ & $\begin{array}{l}0.0097 \\
71.42\end{array}$ & $\begin{array}{l}0.0104 \\
66.50\end{array}$ \\
\hline
\end{tabular}

Note: Numbers in brackets refer to the p-values.

Similarly, irrespective of which the connectivity matrix was applied in the spatial models, parameters $\rho$ and $\lambda$ are statistically significant. It is worth noting that the fact of including the connectivity matrixes in the considered models has a crucial impact on convergence parameters $(\beta)$. Absolute values 
of the parameters for the SAR and SE models are lower than for the traditional model which does not take into account the connections across the investigated stock exchanges.

Table 5. Results of the estimation and verification of panel models with fixed effects obtained for the European stock exchanges - variant I

\begin{tabular}{|c|c|c|c|}
\hline & FE_IND & SAR_FE_IND & SE_FE_IND \\
\hline \multicolumn{4}{|l|}{ Parameters } \\
\hline$\alpha$ & $\begin{array}{l}-1.6250 \\
(0.0000)\end{array}$ & $\begin{array}{l}-1.2397 \\
(0.0000)\end{array}$ & $\begin{array}{l}-1.5821 \\
(0.0000)\end{array}$ \\
\hline$\beta$ & $\begin{array}{l}-0.8927 \\
(0.0000)\end{array}$ & $\begin{array}{l}-0.6785 \\
(0.0000)\end{array}$ & $\begin{array}{l}-0.8696 \\
(0.0000)\end{array}$ \\
\hline$\rho$ & - & $\begin{array}{c}0.3543 \\
(0.0006)\end{array}$ & - \\
\hline$\lambda$ & - & - & $\begin{array}{c}0.5218 \\
(0.0000)\end{array}$ \\
\hline \multicolumn{4}{|l|}{ Goodness of fit } \\
\hline Adjusted R2 & 0.4375 & - & - \\
\hline AIC & -117.1200 & -127.0400 & -132.3600 \\
\hline \multicolumn{4}{|l|}{ Heteroskedasticity } \\
\hline Breuch-Pagan test & $\begin{array}{l}30.4129 \\
(0.0336) \\
\end{array}$ & $\begin{array}{l}27.5709 \\
(0.0689) \\
\end{array}$ & $\begin{array}{l}28.4229 \\
(0.0559) \\
\end{array}$ \\
\hline $\begin{array}{l}\text { Autocorrelation of } \\
\text { residuals } \\
\text { Moran test }\end{array}$ & $\begin{array}{l}7.0928 \\
(0.0000)\end{array}$ & $\begin{array}{c}2.0868 \\
(0.0185)\end{array}$ & $\begin{array}{l}-0.4411 \\
(0.3296)\end{array}$ \\
\hline \multicolumn{4}{|l|}{$\begin{array}{c}\text { Spatial } \\
\text { dependence }\end{array}$} \\
\hline LR & - & $\begin{array}{l}11.9190 \\
(0.0006)\end{array}$ & $\begin{array}{l}17.2380 \\
(0.0000)\end{array}$ \\
\hline LMlag & $\begin{array}{l}16.7366 \\
(0.0000)\end{array}$ & - & - \\
\hline LMerr & $\begin{array}{l}38.3239 \\
(0.0000)\end{array}$ & - & - \\
\hline RLMlag & - & $\begin{array}{c}0.1360 \\
(0.7123)\end{array}$ & - \\
\hline RLMerr & - & - & $\begin{array}{l}21.7233 \\
(0.0000) \\
\end{array}$ \\
\hline Chow test $\mathrm{F}$ & - & $\begin{array}{l}65.9038 \\
(0.0000)\end{array}$ & $\begin{array}{l}83.4606 \\
(0.0000)\end{array}$ \\
\hline $\begin{array}{c}\text { Speed of convergence } \\
\text { Half-life }\end{array}$ & $\begin{array}{c}0.2790 \\
2.48\end{array}$ & $\begin{array}{c}0.1418 \\
4.89\end{array}$ & $\begin{array}{c}0.2546 \\
2.72 \\
\end{array}$ \\
\hline
\end{tabular}

Note: Numbers in brackets refer to the p-values.

Tables 5 and 6 contain the results of the estimation and verification of exemplary panel models used in the investigation, i.e. the panel model with fixed effects without the spatial component (FE_IND), the spatial auto-

Dynamic Econometric Models 15 (2015) 5-26 
regressive panel model with fixed effects (SAR_FE_IND), and the spatial error panel model with fixed effects (SE_FE_IND). Just as in the pooled time and cross-sectional data models also in the panel data models the connections among the stock exchanges in two variants (connections according to physical/economic distance) were taken into account. Fixed effects are significant in the considered models. It means that individual characteristics of every exchange are valid for their convergence.

Table 6. Results of the estimation and verification of panel models with fixed effects obtained for the European stock exchanges - variant II

\begin{tabular}{|c|c|c|c|}
\hline & FE_IND & SAR_FE_IND & SE_FE_IND \\
\hline \multicolumn{4}{|l|}{ Parameters } \\
\hline$\alpha$ & $\begin{array}{l}-1.6250 \\
(0.0000)\end{array}$ & $\begin{array}{l}-1.1442 \\
(0.0000)\end{array}$ & $\begin{array}{l}-1.6095 \\
(0.0000)\end{array}$ \\
\hline$\beta$ & $\begin{array}{l}-0.8927 \\
(0.0000)\end{array}$ & $\begin{array}{l}-0.6248 \\
(0.0000)\end{array}$ & $\begin{array}{l}-0.8894 \\
(0.0000)\end{array}$ \\
\hline$\rho$ & - & $\begin{array}{c}0.4542 \\
(0.0000)\end{array}$ & - \\
\hline$\lambda$ & - & - & $\begin{array}{c}0.6309 \\
(0.0000)\end{array}$ \\
\hline $\begin{array}{l}\text { Goodness of fit } \\
\text { Adjusted R2 } \\
\text { AIC }\end{array}$ & $\begin{array}{c}0.4375 \\
-117.1200\end{array}$ & $\begin{array}{c}- \\
-132.0000\end{array}$ & $-\frac{-}{-138.2700}$ \\
\hline $\begin{array}{l}\text { Heteroskedasticity } \\
\text { Breuch-Pagan test }\end{array}$ & $\begin{array}{l}30.4129 \\
(0.0336)\end{array}$ & $\begin{array}{l}27.3471 \\
(0.0727)\end{array}$ & $\begin{array}{l}27.4311 \\
(0.0713)\end{array}$ \\
\hline $\begin{array}{l}\text { Autocorrelation of } \\
\text { residuals } \\
\text { Moran test } \\
\end{array}$ & $\begin{array}{l}7.4093 \\
(0.0000)\end{array}$ & $\begin{array}{l}3.0568 \\
(0.0011) \\
\end{array}$ & $\begin{array}{l}1.2405 \\
(0.1074)\end{array}$ \\
\hline $\begin{array}{c}\text { Spatial } \\
\text { dependence } \\
\text { LR }\end{array}$ & \multicolumn{2}{|c|}{$\begin{array}{c}\text { Spatial } \\
\text { dependence }\end{array}$} & $\begin{array}{l}23.1530 \\
(0.0000)\end{array}$ \\
\hline LMlag & $\begin{array}{l}22.4971 \\
(0.0000)\end{array}$ & - & - \\
\hline LMerr & $\begin{array}{l}41.8167 \\
(0.0000)\end{array}$ & - & - \\
\hline RLMlag & - & $\begin{array}{c}0.4012 \\
(0.5265)\end{array}$ & - \\
\hline RLMerr & - & - & $\begin{array}{l}19.7207 \\
(0.0000)\end{array}$ \\
\hline Chow test $\mathrm{F}$ & - & $\begin{array}{l}22.0179 \\
(0.0000)\end{array}$ & $\begin{array}{l}28.7812 \\
(0.0000)\end{array}$ \\
\hline $\begin{array}{c}\text { Speed of convergence } \\
\text { Half-life }\end{array}$ & $\begin{array}{c}0.2790 \\
2.48\end{array}$ & $\begin{array}{l}0.1225 \\
5.66\end{array}$ & $\begin{array}{c}0.2752 \\
2.52\end{array}$ \\
\hline
\end{tabular}

Note: Numbers in brackets refer to the p-values. 
The diagnostics of the considered models suggests that the classical panel model is the worst among them. In this case, the Breusch-Pagan statistic is significant (at the level of significance $\gamma=0.05$ ), leading to the rejection of the model assumption of homoskedasticity. In addition, on the basis of the Moran test the hypothesis of the independence of the model residuals should be rejected (comp. the TSCS model).

Table 7. Results of the estimation and verification of $\beta$-convergence models for pooled time series and cross-sectional data, obtained for Asian and American stock exchanges - variant I

\begin{tabular}{|c|c|c|c|}
\hline & Linear regression & $\begin{array}{c}\text { Spatial autoregressive } \\
\text { model }\end{array}$ & $\begin{array}{c}\text { Spatial error } \\
\text { model }\end{array}$ \\
\hline \multicolumn{4}{|l|}{ Parameters } \\
\hline$\alpha$ & $\begin{array}{l}-0.4678 \\
(0.0000)\end{array}$ & $\begin{array}{l}-0.4181 \\
(0.0000)\end{array}$ & $\begin{array}{l}-0.3749 \\
(0.0000)\end{array}$ \\
\hline$\beta$ & $\begin{array}{l}-0.2084 \\
(0.0000)\end{array}$ & $\begin{array}{l}-0.1845 \\
(0.0000)\end{array}$ & $\begin{array}{l}-0.1751 \\
(0.0000)\end{array}$ \\
\hline$\rho$ & - & $\begin{array}{c}0.3065 \\
(0.0000)\end{array}$ & - \\
\hline$\lambda$ & - & - & $\begin{array}{c}0.3188 \\
(0.0000)\end{array}$ \\
\hline \multicolumn{4}{|l|}{ Goodness of fit } \\
\hline Adjusted R2 & 0.0987 & - & - \\
\hline $\mathrm{AlC}$ & -31.8650 & -51.2710 & -49.7970 \\
\hline \multicolumn{4}{|l|}{ Heteroskedasticity } \\
\hline Breuch-Pagan test & $\begin{array}{l}18.7771 \\
(0.0000)\end{array}$ & $\begin{array}{l}19.1601 \\
(0.0000)\end{array}$ & $\begin{array}{l}18.4701 \\
(0.0000)\end{array}$ \\
\hline $\begin{array}{l}\text { Autocorrelation of } \\
\text { residuals } \\
\text { Moran test }\end{array}$ & $\begin{array}{c}6.1474 \\
(0.0000)\end{array}$ & $\begin{array}{l}-0.5729 \\
(0.2834)\end{array}$ & $\begin{array}{l}-0.3759 \\
(0.3535)\end{array}$ \\
\hline \multicolumn{4}{|l|}{$\begin{array}{c}\text { Spatial } \\
\text { dependence }\end{array}$} \\
\hline LR & - & $\begin{array}{l}21.4060 \\
(0.0000)\end{array}$ & $\begin{array}{l}19.9320 \\
(0.0000)\end{array}$ \\
\hline LMlag & $\begin{array}{l}39.7261 \\
(0.0000)\end{array}$ & - & - \\
\hline LMerr & $\begin{array}{l}32.3990 \\
(0.0000)\end{array}$ & - & - \\
\hline RLMlag & - & $\begin{array}{l}12.2581 \\
(0.0005)\end{array}$ & - \\
\hline RLMerr & - & - & $\begin{array}{l}4.9310 \\
(0.0264) \\
\end{array}$ \\
\hline Speed of convergence & 0.0292 & 0.0255 & 0.0241 \\
\hline Half-life & 23.73 & 27.19 & 28.81 \\
\hline
\end{tabular}

Note: Numbers in brackets refer to the p-values. 
The necessity of model re-specifications towards the spatial panel models was also confirmed with the Lagrange Multiplier tests. All the tests are statistically significant, except for the robust version (RLMlag), which suggests that the spatial error panel model should be preferred. Moreover, the significance of the spatial effects with the aid of the LR test has been confirmed (see Tables 5 and 6).

Table 8. Results of the estimation and verification of $\beta$-convergence models for pooled time series and cross-sectional data, obtained for Asian and American stock exchanges - variant II

\begin{tabular}{|c|c|c|c|}
\hline & Linear regression & $\begin{array}{c}\text { Spatial autoregressive } \\
\text { model }\end{array}$ & $\begin{array}{c}\text { Spatial error } \\
\text { model }\end{array}$ \\
\hline \multicolumn{4}{|l|}{ Parameters } \\
\hline$\alpha$ & $\begin{array}{l}-0.4678 \\
(0.0000)\end{array}$ & $\begin{array}{l}-0.3915 \\
(0.0000)\end{array}$ & $\begin{array}{l}-0.3812 \\
(0.0002)\end{array}$ \\
\hline$\beta$ & $\begin{array}{l}-0.2084 \\
(0.0000)\end{array}$ & $\begin{array}{l}-0.1751 \\
(0.0000)\end{array}$ & $\begin{array}{l}-0.2014 \\
(0.0000)\end{array}$ \\
\hline$\rho$ & - & $\begin{array}{l}0.6866 \\
(0.0000)\end{array}$ & - \\
\hline$\lambda$ & - & - & $\begin{array}{c}0.7268 \\
(0.0000) \\
\end{array}$ \\
\hline \multicolumn{4}{|l|}{ Goodness of fit } \\
\hline Adjusted R2 & 0.0987 & - & - \\
\hline AIC & -31.8650 & -73.7960 & -76.4300 \\
\hline \multicolumn{4}{|l|}{ Heteroskedasticity } \\
\hline Breuch-Pagan test & $\begin{array}{l}18.7771 \\
(0.0000)\end{array}$ & $\begin{array}{l}18.4305 \\
(0.0000)\end{array}$ & $\begin{array}{l}17.8364 \\
(0.0000)\end{array}$ \\
\hline $\begin{array}{l}\text { Autocorrelation of } \\
\text { residuals } \\
\text { Moran test } \\
\end{array}$ & $\begin{array}{l}11.8902 \\
(0.0000) \\
\end{array}$ & $\begin{array}{l}1.7776 \\
(0.0377) \\
\end{array}$ & $\begin{array}{c}1.8976 \\
(0.0289) \\
\end{array}$ \\
\hline $\begin{array}{c}\text { Spatial } \\
\text { dependence } \\
\text { LR }\end{array}$ & - & $\begin{array}{l}43.9310 \\
(0.0000)\end{array}$ & $\begin{array}{l}46.5650 \\
(0.0000)\end{array}$ \\
\hline LMlag & $\begin{array}{l}120.0009 \\
(0.0000)\end{array}$ & - & - \\
\hline LMerr & $\begin{array}{l}117.0748 \\
(0.0000)\end{array}$ & - & - \\
\hline RLMlag & - & $\begin{array}{c}3.2764 \\
(0.0703)\end{array}$ & - \\
\hline RLMerr & - & - & $\begin{array}{c}0.3503 \\
(0.5540)\end{array}$ \\
\hline $\begin{array}{c}\text { Speed of convergence } \\
\text { Half-life }\end{array}$ & $\begin{array}{l}0.0292 \\
23.73\end{array}$ & $\begin{array}{l}0.0241 \\
28.81\end{array}$ & $\begin{array}{l}0.0281 \\
24.66\end{array}$ \\
\hline
\end{tabular}

Note: Numbers in brackets refer to the p-values. 
For the purpose of investigating the reasonableness of including the fixed effects in the spatial models there was applied the Chow test which considers the spatial model for pooled TSCS data vs. the spatial panel model with fixed effects. The results of the Chow test have pointed out the statistical significance of the fixed effects in the spatial autoregressive panel model, as well as in the panel spatial error model (see Tables 5 and 6).

Table 9. Results of the estimation and verification of panel models with fixed effects obtained for Asian and American stock exchanges - variant I

\begin{tabular}{|c|c|c|c|}
\hline & FE_IND & SAR_FE_IND & SE_FE_IND \\
\hline \multicolumn{4}{|l|}{ Parameters } \\
\hline$\alpha$ & $\begin{array}{l}-1.5180 \\
(0.0000)\end{array}$ & $\begin{array}{l}-1.4074 \\
(0.0000)\end{array}$ & $\begin{array}{l}-1.4489 \\
(0.0000)\end{array}$ \\
\hline$\beta$ & $\begin{array}{l}-0.9213 \\
(0.0000)\end{array}$ & $\begin{array}{l}-0.8537 \\
(0.0000)\end{array}$ & $\begin{array}{l}-0.8805 \\
(0.0000)\end{array}$ \\
\hline$\rho$ & - & $\begin{array}{c}0.2192 \\
(0.0000)\end{array}$ & - \\
\hline$\lambda$ & - & - & $\begin{array}{c}0.2941 \\
(0.0000) \\
\end{array}$ \\
\hline \multicolumn{4}{|l|}{ Goodness of fit } \\
\hline Adjusted R2 & 0.4167 & - & - \\
\hline AIC & -94.2000 & -107.3700 & -107.9300 \\
\hline \multicolumn{4}{|l|}{ Heteroskedasticity } \\
\hline Breuch-Pagan test & $\begin{array}{l}43.7765 \\
(0.0081) \\
\end{array}$ & $\begin{array}{l}47.0493 \\
(0.0033) \\
\end{array}$ & $\begin{array}{l}46.0142 \\
(0.0044)\end{array}$ \\
\hline $\begin{array}{l}\text { Autocorrelation of } \\
\text { residuals } \\
\text { Moran test } \\
\end{array}$ & $\begin{array}{c}5.4701 \\
(0.0000) \\
\end{array}$ & $\begin{array}{c}0.7071 \\
(0.2397) \\
\end{array}$ & $\begin{array}{l}-0.0850 \\
(0.4661) \\
\end{array}$ \\
\hline \multicolumn{4}{|l|}{$\begin{array}{c}\text { Spatial } \\
\text { dependence }\end{array}$} \\
\hline LR & - & $\begin{array}{l}15.1720 \\
(0.0000)\end{array}$ & $\begin{array}{l}15.7270 \\
(0.0000)\end{array}$ \\
\hline LMlag & $\begin{array}{l}23.3580 \\
(0.0000)\end{array}$ & - & - \\
\hline LMerr & $\begin{array}{l}24.4627 \\
(0.0000)\end{array}$ & - & - \\
\hline RLMlag & - & $\begin{array}{l}3.2420 \\
(0.0718)\end{array}$ & - \\
\hline RLMerr & - & - & $\begin{array}{l}4.3467 \\
(0.0371)\end{array}$ \\
\hline Chow test $\mathrm{F}$ & - & $\begin{array}{l}123.4199 \\
(0.0000)\end{array}$ & $\begin{array}{l}129.7126 \\
(0.0000)\end{array}$ \\
\hline $\begin{array}{c}\text { Speed of convergence } \\
\text { Half-life }\end{array}$ & $\begin{array}{c}0.3178 \\
2.18\end{array}$ & $\begin{array}{c}0.2403 \\
2.88\end{array}$ & $\begin{array}{c}0.2656 \\
2.61\end{array}$ \\
\hline
\end{tabular}

Note: Numbers in brackets refer to the p-values. 
Taking into account the geographical connections (variant I) among the European stock exchanges investigated, in the panel convergence models there has been removed the problem of autocorrelation of the residuals (in the spatial autoregressive panel model at the level of significance $\gamma=0.01)$. However, in the case of using the matrix of economic distance (variant II) the residual autocorrelation has been eliminated only from the spatial error panel model.

Table 10. Results of the estimation and verification of panel models with fixed effects obtained for Asian and American stock exchanges - variant II

\begin{tabular}{|c|c|c|c|}
\hline & FE_IND & SAR_FE_IND & SE_FE_IND \\
\hline \multicolumn{4}{|l|}{ Parameters } \\
\hline$\alpha$ & $\begin{array}{l}-1.5180 \\
(0.0000)\end{array}$ & $\begin{array}{l}-1.3046 \\
(0.0000)\end{array}$ & $\begin{array}{l}-1.3980 \\
(0.0000)\end{array}$ \\
\hline$\beta$ & $\begin{array}{l}-0.9213 \\
(0.0000)\end{array}$ & $\begin{array}{l}-0.7933 \\
(0.0000)\end{array}$ & $\begin{array}{l}-0.8588 \\
(0.0000)\end{array}$ \\
\hline$\rho$ & - & $\begin{array}{c}0.5110 \\
(0.0000)\end{array}$ & - \\
\hline$\lambda$ & - & - & $\begin{array}{c}0.6899 \\
(0.0000)\end{array}$ \\
\hline \multicolumn{4}{|l|}{ Goodness of fit } \\
\hline Adjusted R2 & 0.4167 & - & - \\
\hline AIC & -94.2000 & -121.4400 & -127.2300 \\
\hline \multicolumn{4}{|l|}{ Heteroskedasticity } \\
\hline Breuch-Pagan test & $\begin{array}{l}43.7765 \\
(0.0081)\end{array}$ & $\begin{array}{l}47.7040 \\
(0.0027)\end{array}$ & $\begin{array}{l}44.2658 \\
(0.0071)\end{array}$ \\
\hline \multicolumn{4}{|l|}{ Autocorrelation of } \\
\hline $\begin{array}{l}\text { residuals } \\
\text { Moran test }\end{array}$ & $\begin{array}{c}9.8500 \\
(0.0000)\end{array}$ & $\begin{array}{c}3.3626 \\
(0.0004)\end{array}$ & $\begin{array}{c}1.4042 \\
(0.0801)\end{array}$ \\
\hline \multicolumn{4}{|l|}{$\begin{array}{c}\text { Spatial } \\
\text { dependence }\end{array}$} \\
\hline LR & - & $\begin{array}{l}29.2450 \\
(0.0000)\end{array}$ & $\begin{array}{l}35.0310 \\
(0.0000)\end{array}$ \\
\hline LMlag & $\begin{array}{l}50.3592 \\
(0.0000)\end{array}$ & - & - \\
\hline LMerr & $\begin{array}{l}76.4993 \\
(0.0000)\end{array}$ & - & - \\
\hline RLMlag & - & $\begin{array}{c}3.6813 \\
(0.0550)\end{array}$ & - \\
\hline RLMerr & - & - & $\begin{array}{l}29.8214 \\
(0.0000)\end{array}$ \\
\hline Chow test $\mathrm{F}$ & - & $\begin{array}{l}41.4627 \\
(0.0000)\end{array}$ & $\begin{array}{l}45.2704 \\
(0.0000)\end{array}$ \\
\hline Speed of convergence & 0.3178 & 0.1971 & 0.2447 \\
\hline Half-life & 2.18 & 3.52 & 2.83 \\
\hline
\end{tabular}

Note: Numbers in brackets refer to the p-values. 
Generally, we may say that the statistical properties of the convergence models of the European stock exchanges are better than of the models obtained in our first study mentioned earlier, in which exchanges from different parts of the world were taken into account.

The other tables show the results of the estimation and verification of the convergence models obtained for Asian and American stock exchanges. Table 7 shows the characteristics of the models obtained for the pooled time series and cross-sectional data in the classical and spatial version (the spatial autoregressive model and the spatial error model), respectively. The spatial components in the spatial models are included through the matrix quantifying the physical distance between the stock exchanges. The characteristics of the spatial models using the matrix of the economic distance in comparison with the characteristics of the model without the spatial connections are presented in Table 8.

In both variants of quantification of relationships between the stock exchanges spatial models are better than the models which do not take into account the connections, in terms of the autocorrelation of residuals. Unfortunately, all the models obtained are characterized by heteroskedasticity of variance. The panel models obtained for Asian and American stock exchanges have the analogical fault (see Tables 9 and 10).

\section{Conclusions}

The analysis confirms the earlier findings that the inclusion of the linkages which result from physical and/or economic distance between the stock exchanges in the models of their convergence is justified. In other words, the results of the investigation provide another evidence for the existence of spatial effects in the empirical models of stock exchanges' convergence.

The earlier study (Szulc et al., 2014) found that the geographical distance has less impact on the process of equalizing differentiation of stock markets then the economic distance between them. In this study the finding was not revealed as clearly. The empirical models of convergence obtained for the European stock exchanges satisfy the basic criteria of statistical verification. Unfortunately, this is not the case of the models obtained for the Asian and American stock exchanges.

The analyses of the process of convergence of stock exchanges should be further continued in terms of methodology as well as for the purpose of searching of properly established spatial regimes. 


\section{References}

Arbia, G. (2006), Spatial Econometrics. Statistical Foundations and Applications to Regional Convergence, Springer-Verlag, Berlin Heidelberg, DOI: http://dx.doi.org/10.1007/3-540-32305-8.

Asgharian, H., Hess, W., Liu, L. (2013), A spatial analysis of international stock market linkages, Journal of Banking \& Finance, 37(12), 4738-4754, DOI: http://dx.doi.org/10.1016/j.jbankfin.2013.08.015.

Aspergis, N., Christou, C., Miller, S. M. (2014), Country and Industry Convergence of Equity Markets: International Evidence from Club Convergence and Clustering, The North American Journal of Economics and Finance, 29(C), 36-58.

Baltagi, B. H., Song, S. H., Koch, W. (2003), Testing Panel Data Regression Models with Spatial Error Correlation, Journal of Econometrics, 117(1), 123-150,

DOI: http://dx.doi.org/10.1016/S0304-4076(03)00120-9.

Caporale, G. M., Erdogan, B., Kuzin, V. (2009), Testing for Convergence in Stock Markets: a Non-Linear Factor Approach, CESifo Working Paper Series No. 2845, DOI: http://dx.doi.org/10.2139/ssrn.1496819.

Demirgus-Kunt, A., Levine, R. (1996), Stock Market, Corporate Finance and Economic Growth: An Overview, The World Bank Economic Review, 10(2), 223-239, DOI: http://dx.doi.org/10.1093/wber/10.2.223.

Fraser, P., Helliar, C. V., Power, D. M. (1994), An Empirical Investigation of Convergence Among European Equity Markets, Applied Financial Economics, 4(2), 149-57, DOI: http://dx.doi.org/10.1080/758523959.

Haining R. (2005), Spatial Data Analysis. Theory and Practice, Cambridge University Press, $3^{\text {th }}$ ed., Cambridge.

Hellwig, Z. (1968), Zastosowanie metody taksonomicznej do typologicznego podziału krajów ze względu na poziom ich rozwoju oraz zasoby i strukturę wykwalifikowanych kadr (The Application of the Taxonomic Method to the Typological Division of a Countries due to Their Level of Development, Resources and Structure of Qualified Personnel), Przeglad Statystyczny (Statistical Survey), z. 4, 307-327.

Koralun-Bereźnicka, J. (2008), Zjawisko konwergencji rynków kapitałowych na rynkach europejskich (The Convergence of the Capital Markets in the European Markets), Studia i Prace Kolegium Zarządzania i Finansów (Working Papers of Collegium of Finance and Management), Szkoła Główna Handlowa w Warszawie, Dom Wydawniczy Elipsa, z. 87, 87-98.

Levine, R., Zelvos, S. (1996), Stock Market Development and Long-Run Growth, The World Bank Economic Review, 10(2), 323-339, DOI: http://dx.doi.org/10.1093/wber/10.2.323.

Login, B., Solnik, F. (2001), Extreme Correlation of International Equity Markets, Journal of Finance, 56(2), 649-676, DOI: http://dx.doi.org/10.1111/0022-1082.00340.

Łuniewska, M., Tarczyński, W. (2006), Metody wielowymiarowej analizy porównawczej na rynku kapitatowym (Methods of Multidimensional Comparative Analysis in the Capital Market), PWN, Warszawa.

Millo, G., Piras, G. (2012), splm: Spatial Panel Data Models in R, Journal of Statistical Software, 47(1), 2-38.

Mutl, J., Pfaffermayr, M. (2011), The Hausman Test in a Cliff and Ord Panel Model, Econometrics Journal, 14(1), 48-76, DOI: http://dx.doi.org/10.1111/j.1368-423X.2010.00325.x. 
Suchecka, J., Łaszkiewicz, E. (2011), The Influence of Spatial and Economic Distance on Changes in the Relationships between European Stock Markets During the Crisis of 2007-2009, Acta Universitatis Lodziensis, Folia Oeconomica, 252, Wydawnictwo Uniwersytetu Łódzkiego, 69-84.

Suchecki, B. (ed.) (2012), Ekonometria przestrzenna II. Modele zaawansowane (Spatial Econometrics II. Advanced Models), Wydawnictwo C.H.Beck, Warszawa.

Szulc, E., Wleklińska, D., Górna, K., Górna, J. (2014), The Significance of Distance Between Stock Exchanges Undergoing the Process of Convergence: an Analysis of Selected World Stock Exchanges During the Period of 2004-2012, Dynamic Econometric Models, 14, 125-144, DOI: http://dx.doi.org/10.12775/DEM.2014.007

Wiśniewski, T. (2003), Do Unii Europejskiej - giełdy krajów kandydackich, (For the European Union - Stock Exchanges of Candidate Countries), Nasz Rynek Kapitatowy (Our Capital Market), 6, 22-25.

Wójcik, D. (2009), The Role of Proximity in Secondary Equity Markets, in Clark, G. L., Dixon, A. D., and Monk, A. H. B. (eds.), Managing Financial Risk. From Global to Local, Oxford University Press. Oxford, 140-162, DOI: http://dx.doi.org/10.1093/acprof:oso/9780199557431.003.

\section{Przestrzenno-czasowa analiza konwergencji poziomu rozwoju wybranych giełd papierów wartościowych w okresie 2004-2012}

$\mathrm{Z}$ a r y s t r e ś c i. Artykuł dotyczy analizy konwergencji wybranych giełd papierów wartościowych z punktu widzenia poziomu ich rozwoju. Przedstawia podejście, które wskazuje na potrzebę uwzględniania przestrzennych i ekonomicznych powiązań między rynkami giełdowymi $\mathrm{w}$ analizach ich konwergencji. Przeprowadzone badanie pokazuje także, że analiza konwergencji giełd $\mathrm{w}$ ustalonym zakresie przestrzennym wymaga podziału rozważanych giełd zgodnie z ustalonymi reżimami przestrzennymi Badanie obejmuje 42 wybrane parkiety, analizowane w okresie 2004-2012. Dane empiryczne odnoszą się do 6 zmiennych diagnostycznych, uznanych jako ważne determinanty rozwoju rynków giełdowych.

S ł o w a k l u c z o w e: giełda papierów wartościowych, konwergencja, reżimy przestrzenne, odległość fizyczna, odległość ekonomiczna, macierz sąsiedztwa, przestrzenne modele panelowe. 